\title{
Inorganic arsenic induces apoptosis through downregulation of Ube2d genes and p53 accumulation in rat proximal tubular cells
}

\author{
Maki Tokumoto',2,3, Jin-Yong Lee², Yasuyuki Fujiwara², Masanobu Uchiyama3,4 \\ and Masahiko Satoh² \\ ${ }^{1}$ Laboratory of Chemical Toxicology and Environmental Health, Showa Pharmaceutical University, \\ 3-3165 Higashi-Tamagawagakuen, Machida, Tokyo 194-8543, Japan \\ ${ }^{2}$ Laboratory of Pharmaceutical Health Sciences, School of Pharmacy, Aichi Gakuin University, \\ 1-100 Kusumoto-cho, Chikusa-ku, Nagoya, Aichi 464-8650, Japan \\ ${ }^{3}$ Elements Chemistry Laboratory, RIKEN, 2-1 Hirosawa, Wako-shi, Saitama 351-0198, Japan \\ ${ }^{4}$ Advanced Elements Chemistry Laboratory, Graduate School of Pharmaceutical Sciences, The University of Tokyo, \\ 7-3-1 Hongo, Bunkyo-ku, Tokyo 113-0033, Japan
}

(Received September 17, 2013; Accepted September 25, 2013)

\begin{abstract}
Ube2d ubiquitin-conjugating enzymes promote p53 ubiquitination and proteasomal degradation. We previously showed that cadmium induced p53-dependent apoptosis through the suppression of expression of Ube2d family genes (Ube $2 d 1$, Ube2d2, Ube $2 d 3$ and Ube $2 d 4$ ) in normal rat proximal tubular cells. Here we examined the effects of inorganic arsenic and inorganic mercury, which induce apoptosis in proximal tubular cells, on cellular protein level of p53 and gene expression of Ube2d family. Inorganic arsenic induced apoptosis with p53 accumulation, and suppressed Ube2d1, Ube2d2 and Ube2d4 expression, but not Ube2d3. On the other hand, although apoptosis was induced in response to inorganic mercury in proximal tubular cells, protein level of p53 was not elevated by inorganic mercury. These results suggest that inorganic arsenic, but not inorganic mercury, may induce p53-dependent apoptotic pathways through downregulation of gene expression of Ube2d family in proximal tubular cells.
\end{abstract}

Key words: Inorganic arsenic, Inorganic mercury, p53, Apoptosis, Ube2d family

\section{INTRODUCTION}

Inorganic arsenic and inorganic mercury are environmental pollutants that adversely affect tissues such as the kidney. In addition, both toxicants are known to induce apoptotic cell death in several types of tissues and cells (Duncan-Achanzar et al., 1996; Homma-Takeda et al., 1999; Jimi et al., 2004; Peraza et al., 2006; Kanda et al., 2008; Yadav et al., 2010). However, the precise molecular mechanism by which apoptotic cell death is induced remains to be elucidated.

Cadmium, which exerts renal toxicity, induces apoptosis in proximal tubular cells via several pathways, including the endoplasmic reticulum (ER)-mediated pathway via ER stress and calcium release and the mitochondria-mediated pathway via direct and indirect activation of the mitochondria (Fujiwara et al., 2012). Our recent study demonstrated that cadmium induced p53-dependent apoptotic cell death in proximal tubular cells both in vitro and in vivo (Tokumoto et al., 2011b; Fujiwara et al., 2012). The p53 tumor suppressor functions as an inducer of apoptosis (Sharpless and DePinho, 2002; Mills, 2005). p53 is a short-lived protein, and under normal conditions p53 protein is immediately degraded by the ubiquitin-proteasome system (Haupt et al., 1997; Honda et al., 1997; Kubbutat et al., 1997). In MCF7 human breast carcinoma cells, ubiquitination of p53 was shown to be mediated by Ube $2 \mathrm{~d} 2$ and Ube2d3, which are members of the Ube2d family (Saville et al., 2004). We found that cadmium suppressed the gene expression of all Ube2d family members (Ube2d1, Ube2d2, Ube2d 3 and Ube2d4), and induced accumulation and phosphorylation of $\mathrm{p} 53$, followed by p53-dependent apoptotic cell death (Tokumoto et al., 2011a, 2011b; Fujiwara et al., 2012). Together our

Correspondence: Masahiko Satoh (E-mail: masahiko@dpc.agu.ac.jp) 
data showed that cadmium-induced renal toxicity results from accumulation of p53 through the suppression of expression of the Ube2d family genes.

Similar to cadmium, the environmental pollutants inorganic arsenic and inorganic mercury also induce apoptosis in proximal tubular cells (Duncan-Achanzar et al., 1996; Homma-Takeda et al., 1999; Jimi et al., 2004; Peraza et al., 2006; Kanda et al., 2008). Therefore, we speculated that these two toxicants cause apoptosis in proximal tubular cells through the p53-dependent apoptotic pathway. In the present study, we aimed to clarify the involvement of intracellular accumulation of p53 and downregulation of Ube2d family gene expression in inorganic arsenic- and inorganic mercury-induced apoptosis in NRK-52E normal rat proximal tubular cells.

\section{MATERIALS AND METHODS}

\section{Cell culture and treatments}

NRK-52E cells were purchased from American Type Culture Collection (ATCC; Manassas, VA, USA) and grown in Dulbecco's modified Eagle's medium (DMEM) (Nissui Pharmaceutical, Tokyo, Japan) supplemented with $10 \%$ fetal bovine serum solution (FBS; Life Technologies, Carlsbad, CA, USA), 29.2 g/1 L-glutamine (Nacalai Tesque, Kyoto, Japan), $50 \mathrm{IU} / \mathrm{ml}$ penicillin, $50 \mu \mathrm{g} / \mathrm{ml}$ streptomycin (Dainippon Sumitomo Pharma, Osaka, Japan), and $1.5 \mathrm{~g} / 1$ sodium bicarbonate (Wako Pure Chemical Industries, Osaka, Japan). NRK-52E cells were maintained in $100-\mathrm{mm}$ dishes at $37^{\circ} \mathrm{C}$ in a humid atmosphere of $5 \% \mathrm{CO}_{2}$. Cells were plated for experiments at a density of $1.2 \times 10^{4}$ cells $/ \mathrm{cm}^{2}$ and cultured until confluence. Culture medium was then discarded and cells were washed twice with serum-free DMEM. The cells were incubated with $50 \mu \mathrm{M}$ mercuric chloride $\left(\mathrm{HgCl}_{2}\right), 20 \mu \mathrm{M}$ sodium arsenite $\left(\mathrm{NaAsO}_{2}\right)$ or $10 \mu \mathrm{M}$ cadmium chloride $\left(\mathrm{CdCl}_{2}\right)$ (Wako Pure Chemical Industries) for 6 or $24 \mathrm{hr}$ before harvest.

\section{Cytotoxicity assay}

MTT (3-(4,5-Dimethyl-2-thiazolyl)-2,5-diphenyl-2Htetrazolium bromide; DOJINDO Laboratories, Kumamoto, Japan) assay was used to estimate cell viability. After treatment, cultured medium was changed to fresh $10 \%$ FBS-DMEM containing MTT and incubated for another $4 \mathrm{hr}$ at $37^{\circ} \mathrm{C}$. After removing the medium, dimethyl sulfoxide (Wako Pure Chemical Industries) was added to MTT formazan. Absorbance at $540 \mathrm{~nm}$ was measured by an iMark microplate absorbance reader (Bio-Rad Laboratories, Hercules, CA, USA).

\section{Extraction of total RNA and real-time RT-PCR}

After treatment, the cells were washed twice with calcium- and magnesium-free phosphate buffered saline [PBS(-); Nissui Pharmaceutical]. Total RNA was extracted with the Quick Gene RNA cultured cell kit S (Fujifilm, Tokyo, Japan), including an on-column DNase I (Takara Bio, Shiga, Japan) treatment step, and QuickGene-810 (Fujifilm). cDNA was generated from total RNA using the PrimeScript reverse transcription (RT) Reagent Kit (Perfect Real Time) (Takara Bio). Real-time PCR was performed with the SYBR Premix Ex TaqII (Perfect Real Time) (Takara Bio) and Thermal Cycler Dice Real Time System (Takara Bio). PCR primers used are as follows: 5'-cgggacccgtgggagatgacttgtt-3' (sense) and 5'-gactccaccttgataggcgctgtcg-3' (antisense) for Ube $2 d 1$; 5'-gcacatgtttacctgacacagca-3' (sense) and 5'-cggagaactggcttctcacac-3' (antisense) for Ube $2 d 2$; 5'-gacggttttcagggttctgg-3' (sense) and 5'-tcttcttctcacaccggctct-3' (antisense) for Ube $2 d 3$; 5'-agccttctccaggcataacc-3' (sense) and 5'-taggttggggacctttaccc-3' (antisense) for Ube $2 d 4 ; 5^{\prime}$-taattgaagggtcatgcctaagtgt-3' (sense) and 5'-gctgcctccgacttaactgc-3' (antisense) for $M d m 2$; 5'-cctatccggtcagttgttgga-3' (sense) and $5^{\prime}$-ttgcagagtggaggaaatgg-3' (antisense) for $p 53$; 5'-catggcctccaaggagtaag-3' (sense) and 5'-ggtctgggatggaattgtga-3' (antisense) for Gapdh.

\section{Detection of DNA fragmentation}

After treatment, cells were harvested by scraping with a rubber policeman in ice-cold PBS(-) and centrifuged at $250 \times \mathrm{g}$ for $10 \mathrm{~min}$. Cell pellets were dissolved into $100 \mu \mathrm{l}$ cell lysis buffer [50 mM Tris- $\mathrm{HCl}$ buffer, $\mathrm{pH} 6.8$, $2 \%$ sodium dodecyl sulfate (SDS) and 10\% glycerol] at $4{ }^{\circ} \mathrm{C}$. After $10 \mathrm{~min}$, dissolved samples were centrifuged at $16,000 \times g$ for $5 \mathrm{~min}$ and the supernatants were transferred to new tubes. Two microliters of $20 \mathrm{mg} / \mathrm{ml}$ RNase A solution (Life Technologies) was added and samples were incubated at $37^{\circ} \mathrm{C}$ for $1 \mathrm{hr}$. Two microliters of 10 g/l Proteinase K solution (Life Technologies) was added and samples incubated at $50^{\circ} \mathrm{C}$ for $30 \mathrm{~min}$. Samples were mixed with $20 \mu \mathrm{l}$ of $5 \mathrm{M} \mathrm{NaCl}$ and $120 \mu \mathrm{l}$ isopropanol, and cooled at $-20^{\circ} \mathrm{C}$ for over $20 \mathrm{~min}$. The mixed solutions were centrifuged at $16,000 \times g$ for $15 \mathrm{~min}$ and pellets were resuspended with $10 \mu \mathrm{TE}$ buffer $(10 \mathrm{mM}$ Tris-HCl buffer, $\mathrm{pH} 7.4,1 \mathrm{mM}$ EDTA). DNA fragments were electrophoresed on $2 \%$ agarose gels and visualized by ethidium bromide staining. 
p53 accumulation by arsenic in kidney cells

\section{Western blot analysis}

Anti-p53 rabbit polyclonal antibody and anti- $\beta$-actin mouse monoclonal antibody were obtained from Cell Signaling Technology (Danvers, MA, USA) and American Research Products (Waltham, MA, USA), respectively. After treatment, cells were washed twice with ice-cold PBS(-) and harvested by cell lysis SDS buffer. Cell lysates were boiled at $95^{\circ} \mathrm{C}$ for $15 \mathrm{~min}$ and protein concentrations were measured by BCA protein assay (Thermo Fisher Scientific, Waltham, MA, USA). Samples $(50 \mu \mathrm{g})$ were mixed with a fifth volume of SDS-polyacrylamide gel electrophoresis (SDS-PAGE) loading buffer and separated by SDS-PAGE. Electrophoresed proteins were transferred to a polyvinylidene fluoride membrane. The membrane was blocked in $5 \%$ skim milk in TTBS $(20 \mathrm{mM}$ Tris- $\mathrm{HCl}$ buffer, $\mathrm{pH} 7.5,150 \mathrm{mM} \mathrm{NaCl}, 0.1 \%$ Tween-20) for $1 \mathrm{hr}$. The membrane was washed briefly with TTBS and incubated with appropriate antibodies overnight at $4^{\circ} \mathrm{C}$. Peroxidase-conjugating secondary antibodies (GE Healthcare, Tokyo, Japan) were probed and immunoreactive proteins were detected by enhanced chemiluminescence using Chemi-Lumi One L (Nacalai Tesque).

\section{Statistical analysis}

The data are presented as mean \pm standard deviation (S.D.) for each experimental group $(n=3-4)$. Statistical analyses were performed using one-way analysis of variance (ANOVA) followed by Bonferroni-type multiple $t$-test (parametric). Differences between the groups were considered significant at $P<0.05$.

\section{RESULTS}

\section{Inorganic arsenic and inorganic mercury induce apoptotic cell death through different pathways}

To elucidate whether p53 is involved in NRK-52E cell apoptosis induced by other nephrotoxic substances, particularly toxic metal(loid)s, we examined the effects of inorganic arsenic and inorganic mercury on the induction of apoptosis and p53 protein level. Sodium arsenite at $20 \mu \mathrm{M}$ caused cytotoxicity only in the $24 \mathrm{hr}$ treatment group (Fig. 1A). The viability of NRK-52E cells after treatment with $50 \mu \mathrm{M}$ mercuric chloride for 6 and $24 \mathrm{hr}$ decreased to $77.3 \%$ and $61.6 \%$, respectively (Fig. 1B). Under these conditions, the following analyses were conducted.

We next examined the effects of mercuric chloride and sodium arsenite on the induction of apoptosis using the DNA ladder assay. After $24 \mathrm{hr}$ treatment, DNA fragmentation in mercuric chloride- and sodium arsenite-treated cells, as well as cadmium chloride treated cells, was
A

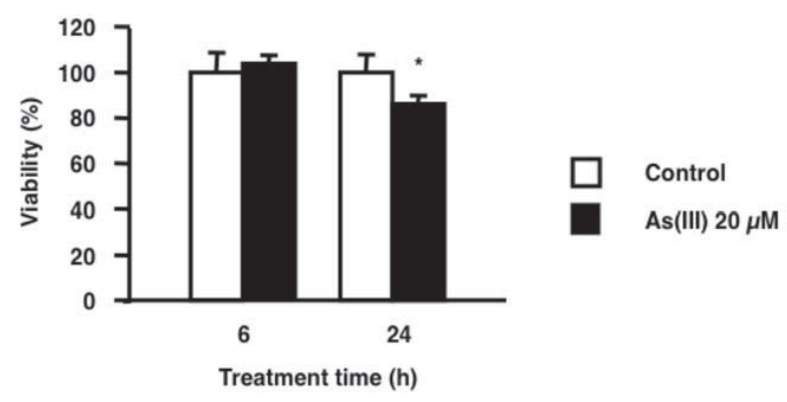

B

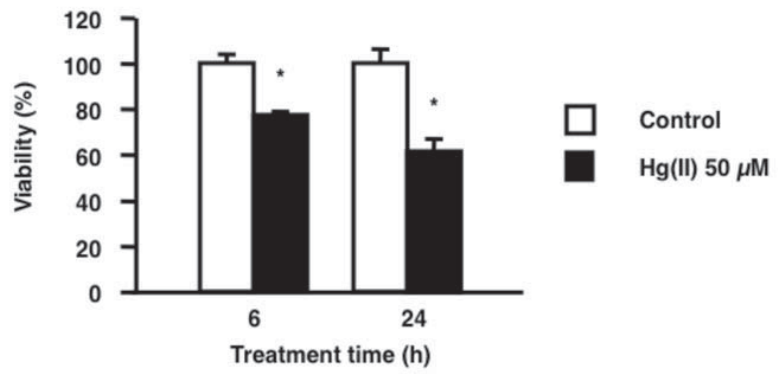

C

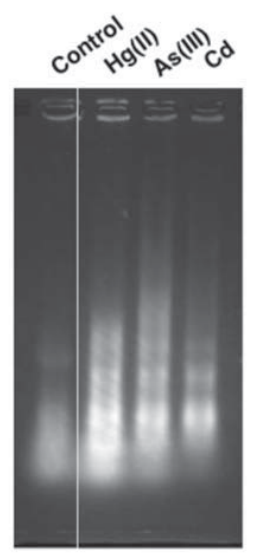

Fig. 1. Effects of inorganic arsenic and inorganic mercury on cytotoxicity and intracellular p53 accumulation. (A) Viability of NRK-52E cells treated with $20 \mu \mathrm{M}$ sodium arsenite [As(III)] for 6 and $24 \mathrm{hr}$. (B) Viability of NRK-52E cells treated with $50 \mu \mathrm{M}$ mercuric chloride $[\mathrm{Hg}(\mathrm{II})]$ for 6 and $24 \mathrm{hr}$. Values are means \pm S.D. for 3-4 samples. * Significant difference from corresponding control, $P<0.05$. (C) DNA fragmentation in NRK-52E cells treated with $50 \mu \mathrm{M}$ mercuric chloride $[\mathrm{Hg}(\mathrm{II})], 20 \mu \mathrm{M}$ sodium arsenite $[\mathrm{As}(\mathrm{III})]$ and $10 \mu \mathrm{M}$ cadmium chloride (Cd) for $24 \mathrm{hr}$. DNA fragments were separated by $2 \%$ agarose gel electrophoresis.

markedly observed (Fig. 1C). In addition, sodium arsenite treatment induced $\mathrm{p} 53$ protein level, as did cadmium chloride, whereas no significant changes in p53 were observed in response to mercuric chloride treatment (Fig. 2). 


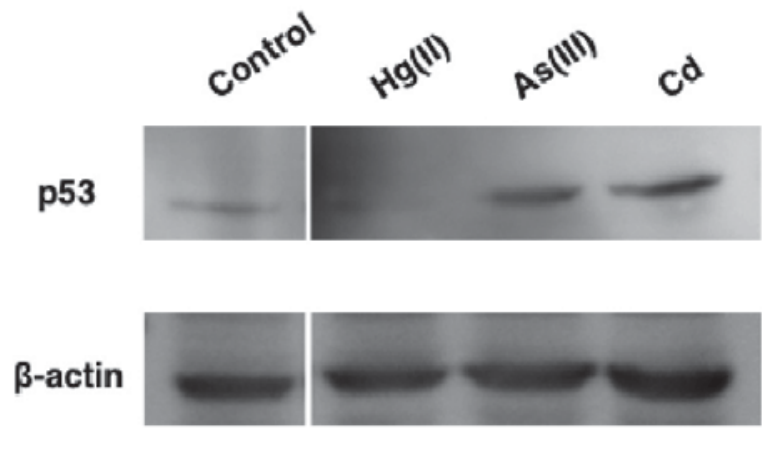

Fig. 2. Effects of inorganic arsenic and inorganic mercury on the protein level of p53 in NRK-52E cells. Western blot analysis of intracellular $\mathrm{p} 53$ protein levels in NRK-52E cells treated with $50 \mu \mathrm{M}$ mercuric chloride $[\mathrm{Hg}(\mathrm{II})], 20 \mu \mathrm{M}$ sodium arsenite [As(III)] and $10 \mu \mathrm{M}$ cadmium chloride $(\mathrm{Cd})$ for $24 \mathrm{hr}$. $\beta$-actin was used as a control to confirm equal loading.

These results indicate that inorganic arsenic and inorganic mercury induce apoptotic cell death in NRK-52E cells through different mechanisms.

\section{Effects of inorganic arsenic and inorganic mercury on the expression of Ube2d family genes}

To test whether the expression levels of the Ube2d family genes are affected by inorganic arsenic, NRK$52 \mathrm{E}$ cells were incubated with sodium arsenite for $6 \mathrm{hr}$ and mRNA levels of Ube2d family genes were examined. Real-time RT-PCR data revealed that sodium arsenite significantly reduced Ube $2 d 1$, Ube $2 d 2$ and Ube $2 d 4$ mRNA levels, whereas $U b e 2 d 3$ mRNA level remained unchanged (Fig. 3A). Conversely, mercuric chloride caused a decrease of only Ube $2 d 1 \mathrm{mRNA}$ (Fig. 3B). These results indicate that inorganic arsenic, as well as cadmium, downregulates the expression of the Ube2d family genes, except for Ube2d3.

\section{Effect of inorganic arsenic on the gene expressions of Mdm2 and p53}

The stability of p53 protein is regulated by $\mathrm{Mdm} 2$, which is the ubiquitin-ligase enzyme specific to p53 (Kubbutat et al., 1997). To examine whether the gene expression of Mdm2 is affected by inorganic arsenic, NRK-52E cells were incubated with sodium arsenite for $6 \mathrm{hr}$ and the mRNA level of Mdm2 and transcription level of $p 53$ were examined. The results showed that $M d m 2$ mRNA and $p 53$ mRNA remained unchanged in response to sodium arsenite (Fig. 4). These results suggest that
A

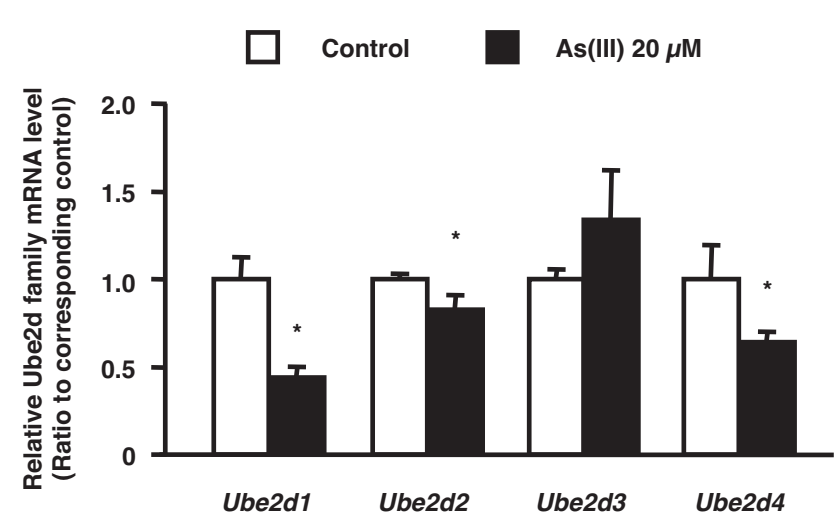

B

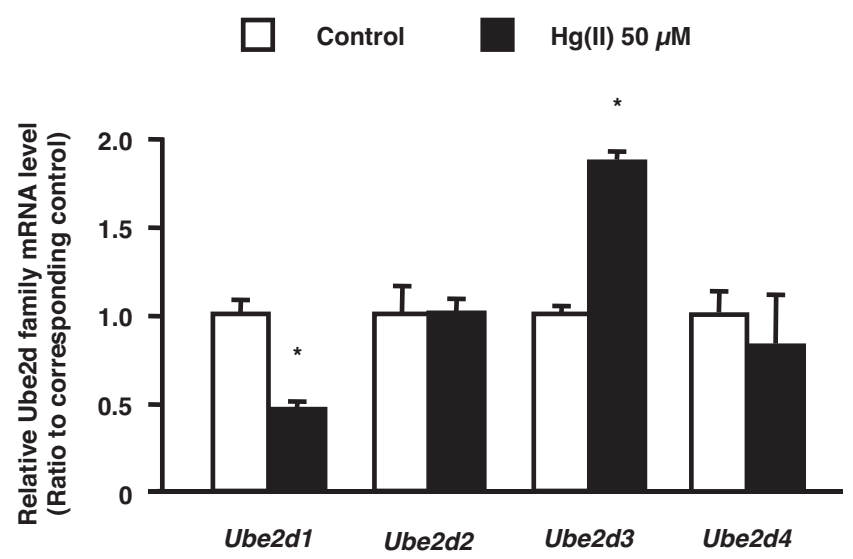

Fig. 3. Effects of inorganic arsenic and inorganic mercury on the gene expression of Ube2d family members in NRK-52E cells. (A) NRK-52E cells were treated with $20 \mu \mathrm{M}$ sodium arsenite [As(III)] for $6 \mathrm{hr}$. mRNA levels of each indicate gene were determined by real-time RT-PCR. (B) NRK-52E cells were treated with $50 \mu \mathrm{M}$ mercuric chloride $[\mathrm{Hg}(\mathrm{II})]$ for $6 \mathrm{hr}$. mRNA levels of each indicate gene were determined by real-time RTPCR. Ube2d family mRNA levels were normalized to Gapdh mRNA levels. Values are means \pm S.D. for 3-4 samples. * Significant difference from corresponding control, $P<0.05$.

intracellular accumulation of p53 induced by inorganic arsenic is controlled by the ubiquitin-conjugating system rather than transcriptional regulation. 
p53 accumulation by arsenic in kidney cells

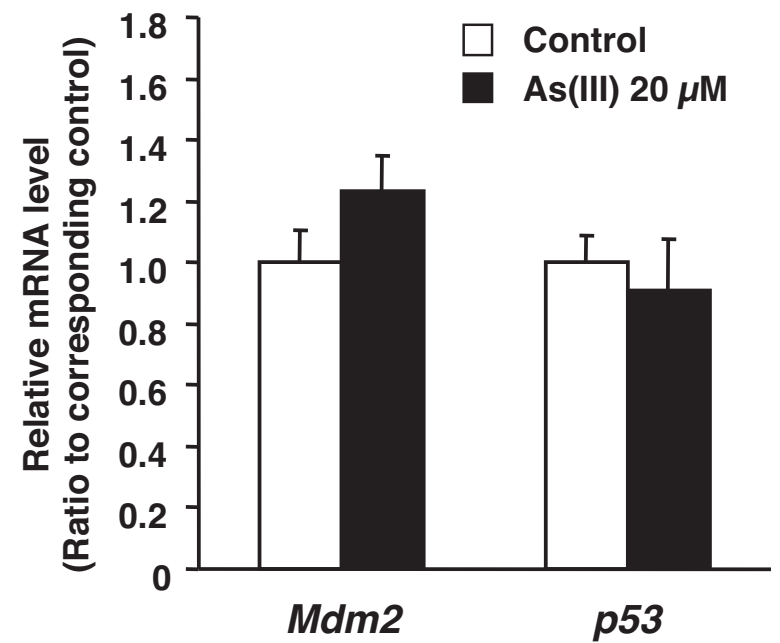

Fig. 4. Effect of inorganic arsenic on $M d m 2$ and $p 53$ gene expression in NRK-52E cells. NRK-52E cells were treated with $20 \mu \mathrm{M}$ sodium arsenite [As(III)] for $6 \mathrm{hr}$. $M d m 2$ and $p 53$ mRNA levels were determined by realtime RT-PCR and normalized to corresponding Gapdh mRNA levels. Values are means \pm S.D. for 3-4 samples.

\section{DISCUSSION}

Our previous study demonstrated that cadmium induced apoptosis accompanied with an increase in intracellular p53 accumulation in NRK-52E cells (Tokumoto et al., 2011b). The present study shows that, similar to cadmium, inorganic arsenic also increased intracellular p53 protein level and induced apoptosis in NRK-52E cells. In addition, inorganic arsenic caused a decrease in mRNA levels of Ube2d1, Ube $2 d 2$ and Ube $2 d 4$ without significant changes in $p 53$ and $M d m 2$ gene expression. Because the ubiquitin proteasome system plays a major role in the degradation of $\mathrm{p} 53$, these findings suggest that inorganic arsenic as well as cadmium suppresses the expression of the Ube2d family genes, resulting in induction of p53 accumulation and p53-dependent apoptosis in NRK-52E cells.

Although a previous study showed that inorganic arsenic increased p53 protein level in murine embryonic fibroblasts through the suppression of p53 degradation (Yu et al., 2013), the underlying mechanisms were unclear. In the present study, our results suggest that inorganic arsenic-induced suppression of Ube2d family gene expression may contribute to the suppression of p53 degradation. Further studies are required to determine whether inorganic arsenic incudes downregulation of Ube2d family genes in other cell lines.

In contrast to inorganic arsenic, inorganic mercury did not affect p53 protein level, even though apoptosis was induced drastically by mercury treatment. Inorganic mercury is known to induce apoptosis through the mitochondria-mediated pathway in various cell lines (Stacchiotti et al., 2009; Chen et al., 2010). In addition, oxidative stresses are known to induce mitochondriamediated apoptosis in NRK-52E cells (Xu et al., 2006; Taneda et al., 2010; Kim et al., 2012). Therefore, inorganic mercury may induce apoptosis through the mitochondria-mediated pathway, but not the p53-dependent pathway, in NRK-52E cells.

Inorganic arsenic decreased mRNA levels of $U b e 2 d l$, Ube $2 d 2$ and Ube $2 d 4$, and increased $\mathrm{p} 53$ protein level in NRK-52E cells, with no change in Ube2d3 mRNA level. In contrast, inorganic mercury did not increase in intracellular p53 protein level, and only Ube2dl gene was downregulated by inorganic mercury. These observations suggest that Ube $2 \mathrm{~d} 2$ and Ube $2 \mathrm{~d} 4$ may contribute to the ubiquitination and degradation of p53 in NRK-52E cells. In MCF7 cells, a previous report showed that Ube2d 2 and Ube2d 3 are associated with the ubiquitination of p53 (Saville et al., 2004). Together this shows that specific ubiquitin-conjugating enzymes promote p53 ubiquitination, depending on the various cell types.

Saville et al. (2004) reported that suppression of expression of Ube $2 d$ family genes causes increased $\mathrm{p} 53$ protein level with continuous transcription of $\mathrm{p} 53$ and Mdm2 in MCF7 cells. p53 induces apoptosis by promoting the transcription of pro-apoptotic factors (Fricker et al., 2010). Mdm2 not only acts as a ubiquitin-ligase enzyme for p53 but also represses transcription activity of p53, therefore high level of Mdm2 result in reduced transcriptional activity of p53 (Saville et al., 2004). Cadmium was found to decrease the expression of the $M d m 2$ gene as well as Ube2d family genes (Tokumoto et al., 2011b). Therefore, in NRK-52E cells, cadmium induces p53-dependent apoptosis through enhanced p53 transcriptional activity that results from accumulation of $\mathrm{p} 53$ protein caused by downregulation of not only Ube2d family genes, but also of the Mdm2 gene. In the present study, inorganic arsenic did not decrease $M d m 2$ mRNA level in NRK-52E cells. Although inorganic arsenic caused downregulation of Ube2d1, Ube2d2 and Ube2 $d 4$, and induction of p53 accumulation and apoptosis, the molecular mechanisms in inorganic arsenic- and cadmium-exposed cells may be different.

In conclusion, our findings show that inorganic arsenic as well as cadmium may induce p53-dependent apoptotic pathways through the downregulation of Ube2d family 
genes in proximal tubular cells. However, inorganic mercury-induced apoptosis in proximal tubular cells is independent of $\mathrm{p} 53$.

\section{ACKNOWLEDGMENT}

This work was supported in part by the Study of the Health Effects of Heavy Metals organized by the Ministry of the Environment, Japan.

\section{REFERENCES}

Chen, Y.W., Huang, C.F., Yang, C.Y., Yen, C.C., Tsai, K.S. and Liu, S.H. (2010): Inorganic mercury causes pancreatic beta-cell death via the oxidative stress-induced apoptotic and necrotic pathways. Toxicol. Appl. Pharmacol., 243, 323-331.

Duncan-Achanzar, K.B., Jones, J.T., Burke, M.F., Carter, D.E. and Laird, H.E. (1996): Inorganic mercury chloride-induced apoptosis in the cultured porcine renal cell line LLC-PK1. J. Pharmacol. Exp. Ther., 277, 1726-1732.

Fricker, M., Papadia, S., Hardingham, G.E. and Tolkovsky, A.M. (2010): Implication of TAp73 in the p53-independent pathway of Puma induction and Puma-dependent apoptosis in primary cortical neurons. J. Neurochem., 114, 772-783.

Fujiwara, Y., Lee, J.Y., Tokumoto, M. and Satoh, M. (2012): Cadmium renal toxicity via apoptotic pathways. Biol. Pharm. Bull., 35, 1892-1897.

Haupt, Y., Maya, R., Kazaz, A. and Oren, M. (1997): Mdm2 promotes the rapid degradation of p53. Nature, 387, 296-299.

Homma-Takeda, S., Takenaka, Y., Kumagai, Y. and Shimojo, N. (1999): Selective induction of apoptosis of renal proximal tubular cells caused by inorganic mercury in vivo. Environ. Toxicol. Pharmacol., 7, 179-187.

Honda, R., Tanaka, H. and Yasuda, H. (1997): Oncoprotein MDM2 is a ubiquitin ligase E3 for tumor suppressor p53. FEBS Lett., 420, 25-27.

Jimi, S., Uchiyama, M., Takaki, A., Suzumiya, J. and Hara, S. (2004): Mechanisms of cell death induced by cadmium and arsenic. Ann. N. Y. Acad. Sci., 1011, 325-331.

Kanda, H., Kikushima, M., Homma-Takeda, S., Sumi, D., Endo, A., Toyama, T., Miura, N., Naganuma, A. and Kumagai, Y. (2008): Downregulation of arginase II and renal apoptosis by inorganic mercury: overexpression of arginase II reduces its apoptosis. Arch. Toxicol., 82, 67-73.

Kim, S.M., Kim, Y.G., Jeong, K.H., Lee, S.H., Lee, T.W., Ihm, C.G. and Moon, J.Y. (2012): Angiotensin II-induced mitochondrial Nox4 is a major endogenous source of oxidative stress in kidney tubular cells. PLoS One, 7, e39739.

Kubbutat, M.H., Jones, S.N. and Vousden, K.H. (1997): Regulation of p53 stability by Mdm2. Nature, 387, 299-303.

Mills, A.A. (2005): p53: link to the past, bridge to the future. Genes Dev., 19, 2091-2099.

Peraza, M.A., Cromey, D.W., Carolus, B., Carter, D.E. and Gandolfi, A.J. (2006): Morphological and functional alterations in human proximal tubular cell line induced by low level inorganic arsenic: evidence for targeting of mitochondria and initiated apoptosis. J. Appl. Toxicol., 26, 356-367.

Saville, M.K., Sparks, A., Xirodimas, D.P., Wardrop, J., Stevenson, L.F., Bourdon, J.C., Woods, Y.L. and Lane, D.P. (2004): Regulation of $\mathrm{p} 53$ by the ubiquitin-conjugating enzymes $\mathrm{UbcH} 5 \mathrm{~B} / \mathrm{C}$ in vivo. J. Biol. Chem., 279, 42169-42181.

Sharpless, N.E. and DePinho, R.A. (2002): p53: good cop/bad cop. Cell, 110, 9-12.

Stacchiotti, A., Morandini, F., Bettoni, F., Schena, I., Lavazza, A., Grigolato, P.G., Apostoli, P., Rezzani, R. and Aleo, M.F. (2009): Stress proteins and oxidative damage in a renal derived cell line exposed to inorganic mercury and lead. Toxicology, 264, 215224

Taneda, S., Honda, K., Tomidokoro, K., Uto, K., Nitta, K. and Oda, H. (2010): Eicosapentaenoic acid restores diabetic tubular injury through regulating oxidative stress and mitochondrial apoptosis. Am. J. Physiol. Renal. Physiol., 299, F1451-F1461.

Tokumoto, M., Ohtsu, T., Honda, A., Fujiwara, Y., Nagase, H. and Satoh, M. (2011a): DNA microarray analysis of normal rat kidney epithelial cells treated with cadmium. J. Toxicol. Sci., 36, 127-129.

Tokumoto, M., Fujiwara, Y., Shimada, A., Hasegawa, T., Seko, Y., Nagase, H. and Satoh, M. (2011b): Cadmium toxicity is caused by accumulation of p53 through the down-regulation of Ube $2 \mathrm{~d}$ family genes in vitro and in vivo. J. Toxicol. Sci., 36, 191-200.

Xu, F., Putt, D.A., Matherly, L.H. and Lash, L.H. (2006): Modulation of expression of rat mitochondrial 2-oxoglutarate carrier in NRK-52E cells alters mitochondrial transport and accumulation of glutathione and susceptibility to chemically induced apoptosis. J. Pharmacol. Exp. Ther., 316, 1175-1186.

Yadav, S., Shi, Y., Wang, F. and Wang, H. (2010): Arsenite induces apoptosis in human mesenchymal stem cells by altering Bcl-2 family proteins and by activating intrinsic pathway. Toxicol. Appl. Pharmacol., 244, 263-272.

Yu, Y., Zhang, D., Huang, H., Li, J., Zhang, M., Wan, Y., Gao, J. and Huang, C. (2013): NF- $\mathrm{kB} 1$ p50 promotes p53 protein translation through miR-190 downregulation of PHLPP1. Oncogene, in press. 